\title{
Characterization and Optimization of Incinerated Municipal Solid Waste Fly Ash as a Cement Substitute Material in Concrete at Reppie Waste to Energy Plant, Ethiopia, East Africa
}

\author{
Abebe Simegn ${ }^{1 *}$, Sisay Abebe ${ }^{2}$ and Abebe Worku \\ ${ }^{1}$ Department of Environmental Engineering, Addis Ababa Science and Technology University, Addis \\ Ababa, Ethiopia \\ ${ }^{2}$ Environmental Pollution Management Research Directorate, Ethiopian Environment and Forest \\ Research Institute, Addis Ababa, Ethiopia
}

\begin{abstract}
Incinerated municipal solid waste fly ash is a byproduct of Reppie Waste to Energy Plant Technology found after generation of power and electricity. The disposal of this ash in the form of particulate matter is already causing serious environmental problems to the city. This research was, therefore, conducted to examine the potential of incinerated municipal solid waste fly ash as a cement substitute material. The incinerated municipal solid waste fly ash of Reppie waste to energy plant after silicate analysis was investigated for the major chemical composition to test the requirement of ASTM C 618 artificial pozzolanic property of class $\mathrm{C}$. This makes it possible to the partial replacement of cement in concrete structure for the construction industry. The samples of this fly ash were arranged in a random and design mix ratio of 1:2:3 with a maximum 0.45 water-cement ratios following EBCS-2, 1995 [1] to survey compressive strength tests, tensile strength, density test, and water absorbency tests. The test result of compressive strength showed that, up to $13.6 \%$ substitution of the standard Ordinary Portland Cement (OPC) by incinerated municipal solid waste fly ash in concrete gratify the targeted compressive strength requirement at 28 days of curing period. While more than $15 \%$ of the substitution showed lower compressive strength at 28 days for M-30 grade of concrete but it works for other grades of the simple concrete structure. Therefore, it can be concluded that $13.6 \%$ replacement of cement by incinerated municipal solid waste fly ash resulted in nearly $30 \mathrm{MPa}$ compressive strength which satisfies the required concrete grade. The higher replacement could also be used for other grades of concrete required such as $M-25, M-20$, and $M-15$ grade of concrete for simple structure in the construction industry by further optimization. Hence, the substitution of incinerated municipal solid waste fly ash from Reppie waste to energy plant for cement in concrete is environmentally promising which further encourages the use of waste as valuable resources thereby solves the problems caused by its direct disposal to the environment.
\end{abstract}

Keywords

Portland cement, Fly ash, Concrete, Fine aggregate, Coarse aggregate, Municipal solid waste

\section{Introduction}

Municipal solid waste (MSW) is a waste containing a dayto-day activity of rejects as an unwanted substance from social exercises such as household and commercial solid wastes $[2,3]$. MSW consists of a compostable division (such as food waste), a combustible division (such as glass, plastics, paper, and materials), dormant division (such as stones, metals, glass, and ceramics), and moisture content that exists within the compostable division $[4,5]$.

The transfer of these wastes, as well as their controlling framework, has got attention. The waste management and utilization approaches are a fundamental issue all over the
*Corresponding author: Abebe Simegn, Department of Environmental Engineering, Addis Ababa Science and Technology University, P.O. Box 16417, Addis Ababa, Ethiopia

Received: September 14, 2020

Accepted: February 13, 2021

Published online: February 15, 2021

Citation: Simegn A, Abebe S, Worku A (2021) Characterization and Optimization of Incinerated Municipal Solid Waste Fly Ash as a Cement Substitute Material in Concrete at Reppie Waste to Energy Plant, Ethiopia, East Africa. Adv Environ Stud 5(1):382-393 
Citation: Simegn A, Abebe S, Worku A (2021) Characterization and Optimization of Incinerated Municipal Solid Waste Fly Ash as a Cement Substitute Material in Concrete at Reppie Waste to Energy Plant, Ethiopia, East Africa. Adv Environ Stud 5(1):382-393

world including Ethiopia. Incineration is a leading technique not only to treat and decrease wastes by volume less than $90 \%$ but also to generate power by recovering energy from municipal solid waste [6]. Incinerated municipal solid waste (IMSW) may handle of burning of strong waste at a temperature of over $900{ }^{\circ} \mathrm{C}$ to change over it into fiery remains and this innovation can diminish the volume of municipal solid waste $[7,8]$. Incinerated municipal solid waste innovation encompasses the potential to produce waste ingredients to be utilized in the construction industry.

The structure of IMSW is somewhat complicated in the generation of coal ash and petroleum ashes. The Incinerated municipal solid waste ashes can be classified into two: Bottom ash and fly ash. Fly Ash (FA) and Bottom Ash (BA) are produced as a by-product from municipal solid waste incinerators and coal-fueled power stations. FA is a highly dispersible powder. It contains mainly aluminosilicate and ferriferous glassy spherical particles (about 60-80\%) and irregularly shaped grains of amorphous clay, mullite quartz, and unburned metamorphic fuel [9]. Bottom ash consists of irregular particles, which can be up to $10-15 \mathrm{~mm}$ in size. The chemical compositions of FA and BA ashes from the same power plant are similar $[10,11]$.

The disposal management practices of incinerated municipal solid waste fly ash residues at Reppie are based on traditional sanitary landfilling techniques that have been generally applied without any significant regulations. Reppie waste to energy project utilizes as feedstock around 1,400 tons per day of MSW and the incinerator yearly capacity is around 100,000 tons. This amount of books around $50 \%$ of municipal solid wastes collected from the city daily (www.eep.gov.et). Hence, collection of municipal solid waste with suitable arrangement plays a great role and IMSW fly ash was collected from Reppie-Waste-to-Energy Plant" which is found in Addis Ababa, Ethiopia. Traditional disposal way of incinerated municipal solid waste fly ash leads a serious environmental, social and economic problems: Transportation of fly ash is difficult since the lightweight particles tend to fly and causing air pollution, long inhalation causes serious respiratory problems, affects horticulture, agriculture and forest fields and requirement of huge land for making ash ponds or dikes, disposal in sea, river or ponds damage the aquatic life and fly ash also causes siltation problems.

Cement is the most widely used building material in the world, with nearly $450 \mathrm{~kg}$ of cement being consumed yearly per capita [12]. Cement is the main and important component in the construction industry but it's more expensive when we compared to other ingredients of concrete materials. Cement is also the leading component of concrete which contains the potential to bind non-cement substances together. When cement blended with water it sets and hardens into a strong mass through the method of hydration. The mining of its raw materials leads to the depletion of natural resources and degradation of the environment. The cement production process is mainly classified into three, the raw material preparation process, the clinker burning process, and the finish grinding process. Off all these processes, clinker burning is the most energy-intensive process, accounting for about more than
$90 \%$ of the fuel consumed and about $30 \%$ of the electric power consumption and the rest about $40 \%$ of the electric power is consumed by the finish grinding process and about $30 \%$ by the raw material preparation [13]. Each tone of cement produced needs nearly $105 \mathrm{kwh}$ of power and $60-130 \mathrm{~kg}$ of fuel oil and it causes approximately $5 \%$ of global man-made $\mathrm{CO}_{2}$ emission, about $50 \%$ emissions are process emissions that occurred during clinker production, $40 \%$ during the burning of fuels to heat the cement kiln and about $10 \%$ come from electricity use and transportation [14]. Its production process is characterized by the consumption of a massive amount of energy and the emission of $\mathrm{CO}_{2}$ to the environment [14]. The effect of $\mathrm{CO}_{2}$ emissions on air pollution contributes to the greenhouse effect, human health by dispersing $\mathrm{O}_{2}$ to the environment, acid rain, and climate change that leads to global warming.

The increase in the demand for cement production leads to a critical issue for all stakeholders of the construction industry for sustainable economic growth, particularly in developing countries. Therefore, there is a need to provide further attention to construction materials with regards to the economy, wise energy utilization, and environmental protection for sustainable development [15].

Using IMSW fly ash as cement replacing material requires only transportation and grinding since the byproduct of the materials available in bulk at Reppie landfill site. This implies using IMSW fly ash to the minimum reduces the cost of clinker production (the most expensive one) by a certain amount, not mentioning the raw material preparations and other costs associated with cement production.

Because of this and other problems associated with mining and use of cement, different journals and kinds of literature were published to find an alternative material that will partially or fully replace ordinary Portland cement in concrete production [16]. They reached an agreement using Supplementary Cementitious Materials (SCM), such as explosion incinerator slag, volcanic ash, silica fume, IMSW fly ash, and bagasse could have a potential partially replace cement in the construction industry, especially for concrete.

The significance of this study would be a contribution to maximizing incinerated municipal solid waste fly ash to cement mix proportion for $\mathrm{M}-30$ grade of concrete and minimizing the effect of municipal solid waste material on the degradation of the environment due to cement demand. Apart from protecting the environment, the main benefits of using incinerated municipal solid waste fly ash as partial replacement of cement also saving our natural resources and energy as well [17]. Other than, a decrease of the cement fabricating costs of demand, and the fractional substitution of cement would make it possible significantly to reduce the gas emissions to the environment. The study was focused on characterization and optimization of incinerated municipal solid waste fly ash collected from Reppie waste to energy plant and assesses its potential use as an alternative material for partial replacement of cement in concrete.

\section{Materials and Experimental Methods}

\section{Materials}

Incinerated Municipal Solid Waste Fly Ash from a mass- 
Citation: Simegn A, Abebe S, Worku A (2021) Characterization and Optimization of Incinerated Municipal Solid Waste Fly Ash as a Cement Substitute Material in Concrete at Reppie Waste to Energy Plant, Ethiopia, East Africa. Adv Environ Stud 5(1):382-393

burn MSW incinerator in Reppie waste to energy plant were collected for full silicate analysis, associated physio-chemical tests, and to verify basic parameters of blended concrete quality. The combustion chambers power plant was burning at a temperature of $600{ }^{\circ} \mathrm{C}$ to $1000{ }^{\circ} \mathrm{C}$ range. The experiment test was undertaken at Ethiopian Geological Survey Center and Laboratory of Addis Ababa Science and Technology University. Dangote Ordinary Portland Cement was also purchased from distributors which meet the Ethiopian Quality Assurance specifications. The fine aggregates or sand used in concrete to fill voids between coarse aggregates were obtained from Langano River. Coarse aggregates were purchased from Kassa and Son's building sister crushing plant to use and reduce the amount of cement paste needed to decrease potential shrinkage. Crushed granite stone conforming to EBCS 2-1995 [1] was used.

\section{Experimental methods}

Chemical compositions of incinerated municipal solid waste fly ash: The chemical composition of MSWI fly ash or Silica analysis ( $\mathrm{Si}, \mathrm{Al}, \mathrm{Fe}, \mathrm{Mg}, \mathrm{Ca}, \mathrm{K}, \mathrm{Na}$, and $\mathrm{S}$ ) was characterizedat the laboratory of Geological Survey of Ethiopia using Atomic Absorption Spectrometer and UV- visible Spector photometer as per BGS standard (BGS, 1993). The Milling, specific gravity, sieving, Loss on Ignition, and moisture content of MSWI fly ash were carried out in the mechanical unit operation laboratory of the Geological Survey of Ethiopia as well. Whereas all other necessarily experimental civil works such that compressive strength, tensile strength, absorption capacity, density, specific gravity, etc. were conducted in the material test laboratory of College of Civil and Architectural Engineering, Addis Ababa Science and Technology University.

Determination of suitable proportion (ratio) of IMSW fly ash content blended with Ordinary Portland cement

The specific gravity, sieve analysis, and Absorption Capacity of fine and coarse aggregate were conducted as per Ethiopian Standard [18]. The specific gravity is the ratio between the weight of the substance and the same volume of water in which the substance or material is assumed to be solid. Absorption capacity refers to the amount of water a solid aggregate material can absorb and both the specific capacity. The water absorption capacity was determined by using the Pycnometer method. The silt content of fine aggregates was conducted by jar test sinceit has a severe effect on the quality of the concrete. The soundness of a blended cement test was performed using the standard Le-chatelier method [18].

\section{Experimental design and mix preparation proce- dures}

Mix Design is a process in which one determines the relative quantities of the ingredients of concrete before mixing to produce concrete of desired properties. The experiment was conducted to substitute cement by adjusting the percentage composition of the concrete mix in the sequence of $0,5,10$, $15,20,25,30$, and $35 \%$ of dried incinerated municipal solid waste fly ash. The percentage of the mixed ratio was random by taking into account average data from different literature reviews and economical valuable perspectives [19].

The mixture that meets all the restrictions and has the lowest quantity for cement and municipal solid waste incinerated fly ash with high compressive strength to cement mixture would be considered an optimal mixture. Mixing various concrete mixes with different percentages of municipal incinerated solid waste fly ash to evaluate the performance parameters of concrete: Workability, compressive strength, tensile strength, concrete density, and water absorption.

\section{Characterization of quality of concrete made of IMSW fly ash as a cement replacement material and compares the quality with $\mathbf{M - 3 0}$ standard}

The workability test of freshly blended fresh Portland cement mixed with MSWI ash concrete test was performed by slump test [1]. Fresh concrete was poured into the mold in three layers, clean and free of moisture, approximately one-third of the mold height, where each layer is tamped 25 strokes and the mold is gradually removed vertically upwards.

Compressive strength tests of hardened concrete sample trail were undertaken with internal assembled oil mold cubes $(150 \mathrm{~mm})$ to prevent concrete adhesion. Each mold filled with two concrete layers and vibrated for 30 seconds. The mold was stripped and cured by completely immersing into the curing basin until the testing date. Then samples were crushed after 7 and 28 days of curing time and identified the best percentage replacement of MSWI fly ash by cement in producing $\mathrm{M}-30$ concrete. The compression test was conducted in the material test laboratory of the College of Civil and Architectural Engineering, Addis Ababa Science and Technology University, and the stress at failure loads calculated as per ES [1].

The splitting tensile strength test is an indirect tension test for concrete and it was carried out on a standard cylinder with a diameter of $15 \mathrm{~cm}$ and height $30 \mathrm{~cm}$ [18]. The density of the test sample at the age of the $28^{\text {th }}$ day for the different levels or proportions of incinerated municipal solid waste fly ash replacement was determined [20]. The water absorption capacity test of hardened concrete was estimated [20].

\section{Quality control}

A preliminary test of materials such that basic concrete quality-related parameters were investigated. Which affect the normal consistency of blended cement paste, soundness test of blended cement paste, sieve analysis and setting time. In addition, basic concrete quality-related parameters (compressive strength, tensile strength, water absorption capacity, and density of hardened blended concrete) were tested for each trial mix ratio to optimize suitable mix proportionof $\mathrm{M}-30$ grade of concrete.

\section{Results and Discussions}

\section{Characteristics of incinerated municipal solid waste fly ash}

Chemical compositions of incinerated municipal solid waste fly ash: The combined chemical composition of Reppie 
Citation: Simegn A, Abebe S, Worku A (2021) Characterization and Optimization of Incinerated Municipal Solid Waste Fly Ash as a Cement Substitute Material in Concrete at Reppie Waste to Energy Plant, Ethiopia, East Africa. Adv Environ Stud 5(1):382-393

fly ash $\left(\mathrm{SiO}_{2}+\mathrm{Al}_{2} \mathrm{O}_{3}+\mathrm{Fe}_{2} \mathrm{O}_{3}=50.0 \%\right)$ testified the pozzolanic nature of fly ash as per ASTM C- 618 specifications (2013). According to this specification, the Reppie incinerated municipal solid waste fly ash qualifies to be a Class C artificial Pozzolan. The more content of pozzolanic properties of materials in concrete used, it increases mechanical strength and durability, lowering the heat of hydration and thermal shrinkage, increase in water tightness, reduction in the alkali-aggregate reaction, resistance to sulfate attack, and better workability. Cost efficiency are also some of the improvements achieved by using pozzolans blended with Portland cement and pozzolans improve lime properties [21].

The chemical compositions or silicate analysis of incinerated municipal solid waste fly ashes were determined (Table 1) [22].

The $\mathrm{CaO}$ content of incinerated municipal solid waste fly ash resulted in nearly one-third of ordinary Portland cement and this implies fully replacement of cement impossible. Because, $\mathrm{CaO}$ content of the ash has impact on concrete soundness and strength [23]. Excessive presence of lime makes cement unsound, causes the cement to expand, and disintegrate, while lime deficiency decreases the strength of the cement's property and allows cement to quickly set. Increasing the quantity of the cemented binder cycle and, to a lesser extent, calcium-aluminate hydrates, enhancing the long-term stability and reducing the system's permeability $[23,24]$. The test result indicates that the calcium content of IMSW fly ash shows $22.54 \%$ which gratifies others experiment that makes it possible to concrete ingredients on behalf of cement $[23,25]$.

On the other hand, the $\mathrm{SiO}_{2}$ content of incinerated municipal solid waste fly ash test result was $30.72 \%$ which is higher than OPC (Table 1). The presence of such content of silicon plays a vital role to increase the pozzolanic property as well as strength of cement. Reppie incinerated municipal solid waste fly ash of $\mathrm{Al}_{2} \mathrm{O}_{3}$ content were $14.96 \%$ which is greater than OPC as a result alumina adds a quick-setting property to cement that means reduce setting time by the increasing rate of hydration. Therefore increasing the percentage replacement of MSWI fly ash will increase alumina content. This needs more water demand to reduce the setting time of producing concrete. The concentration of $\mathrm{MgO}$ and $\mathrm{Fe}_{2} \mathrm{O}_{3}$ in municipal solid waste incinerated fly ash samples slightly increased from Portland cement. Iron oxide provides the color, strength, and hardness of cement. It acts as a flux and forms tri calcium alumino ferrite with calcium and aluminum to impart toughness and strength to cement in the chemical reaction at high temperatures. Magnesium oxide is a very small amount in cement that provides color and hardness. Magnesia should not be present in cement more than $2 \%$, however, the test result indicated that $2.82 \%$ of $\mathrm{MgO}$ present in the sample and due to excess content of magnesia (0.28\%) makes to decrease cement strength.

The MSWI fly ash was found to have high alkali content $\left(\mathrm{Na}_{2} \mathrm{O}\right.$ and $\mathrm{K}_{2} \mathrm{O}$ ) comparable to OPC and it can cause a quick setting, reduce the ultimate strength of concrete, increase expansion underwater, shrinkage under drying conditions and this implies that adding more percentage of incinerated municipal solid waste fly ash to concrete may not be advisable due to its alkali concentration.

High amount of sulfates and chloride content in ashes were dangerous because sulfates and chloride content make more hydration and reduce the setting time of concrete. However, the test result from the silicate analysis of incinerated municipal solid waste fly ash was completely free from sulfate and chloride content. This is to means that concrete produced by blending incinerated municipal solid waste fly ash with OPC may not be exposed to sulfate attack from its source.

Table 1: Shows that, the chemical composition of the fly ash.

\begin{tabular}{|l|l|l|l|}
\hline Chemical composition & Dangote OPC by mass,\% [22] & Reppie IMSW fly ash by mass, \% & OPC cement as per ES, 2005 \\
\hline $\mathrm{SiO}_{2}$ & 22.82 & 30.72 & $18-24$ \\
\hline $\mathrm{Al}_{2} \mathrm{O}_{3}$ & 5.41 & 14.96 & $2.6-8.0$ \\
\hline $\mathrm{Fe}_{2} \mathrm{O}_{3}$ & 3.37 & 3.90 & $1.5-7.0$ \\
\hline $\mathrm{CaO}$ & 66.32 & 22.54 & $61-69$ \\
\hline $\mathrm{MgO}$ & 1.46 & 2.82 & $0.5-4.0$ \\
\hline $\mathrm{Na}_{2} \mathrm{O}$ & - & 3.62 & - \\
\hline $\mathrm{K}_{2} \mathrm{O}$ & - & 8.16 & $0.2-1.0$ \\
\hline $\mathrm{MnO}$ & - & 0.26 & - \\
\hline $\mathrm{P}_{2} \mathrm{O}_{5}$ & - & 2.11 & - \\
\hline $\mathrm{SO}_{3}$ & 2.16 & - & $0.2-4.0$ \\
\hline $\mathrm{TiO}_{2}$ & - & 0.04 & - \\
\hline
\end{tabular}

Table 2: MC and LOI of MSWI Fly ash and ES requirements.

\begin{tabular}{|l|l|l|l|}
\hline Test item & Reppie IMSW fly ash by Mass, \% & Requirements as per ASTM C 618-05 (\%) & OPC cement as per ES 1176-6:2005 \\
\hline MC & 0.15 & 3\%, Max & - \\
\hline LOI & 11.17 & $6 \%$, Max & $4 \%$, Max \\
\hline
\end{tabular}


Citation: Simegn A, Abebe S, Worku A (2021) Characterization and Optimization of Incinerated Municipal Solid Waste Fly Ash as a Cement Substitute Material in Concrete at Reppie Waste to Energy Plant, Ethiopia, East Africa. Adv Environ Stud 5(1):382-393

Moisture Content and Loss on Ignition of IMSW fly ash: The moisture content value for this fly ash was $0.15 \%$ which qualified the standard specified by ASTM C 618 (3\%, Max). However, LOI was $11.17 \%$ which was slightly more than the standard specified by ASTM C 618 (6\%, Max) and the cement standard (max 4\%). A high ignition loss suggests pre-hydration and carbonation that may result from inadequate and prolonged processing. As a result, the MSWI fly ash component is a good indicator of characterizing and assessing its possible use as a partial replacement of cement in concrete (Table 2).

\section{Suitable proportion (ratio) of IMSW fly ash con- tent blended with Portland cement in producing concrete material}

The specific gravity of concrete materials: Specific gravity is the measure of the quality of material from a porosity perspective. The action of the materials in water is usually used in measurements of mixture proportioning which is directly proportional to workability and bonding strength. The specific gravity of the sample was conducted using Pycnometer (Table 3).

In Table 3, the test result shows all samples collected qualified the specified standards but not apparent specific gravity of fine aggregate which was exceeded by $7.7 \%$ from ASTM C 618 requirements (2013). Apparent specific gravity is nothing to concrete quality parameter because the bulk specific gravity of a material is sufficient parameter for mix design of concrete and used all this material to our research directly as it is.

Silt content of fine aggregates: Table 4: The test result of silt content of fine aggregates.

Sieve analysis of fine and coarse aggregates: The Ethiopian Standard requirements of fine aggregate fineness modules range from 2.6 to 2.9 and the test result of the sample (2.4) meets the requirement. Fineness Modulus is used in determining the degree of uniformity of the aggregate gradation and also useful in estimating proportions of fine aggregate to coarse aggregate (Table 5).

Ethiopian has no Standard requirements regarding fineness modules of coarse aggregate and the test result of the sample found to be 3.3. Table 6 indicated that the measured value of the coarse aggregate of the sample's and grain size distribution of coarse aggregate was found to be qualified as per the Ethiopian standard requirements.

The moisture content of fine aggregate and coarse aggregates: The moisture content of concrete material is the amount of water in the aggregate as a proportion of the original weight of the specimen. The moisture content of the coarse aggregate followed by ACl E 1-99 standard was found to be $1.78 \%(2 \%, \max )$ and qualified. Whereas the moisture content of fine aggregate was conducted as per ASTM C 618-5 standard and found to be $6.9 \%$ which was fulfilled the require-

Table 3: Show that, the test result of specific gravity of concrete materials.

\begin{tabular}{|c|c|c|c|c|c|}
\hline \multirow[t]{2}{*}{ No } & \multirow[t]{2}{*}{ Materials } & \multicolumn{3}{|c|}{ The specific gravity of the sample } & \multirow[t]{2}{*}{ Remark } \\
\hline & & Bulk SG & App. SG & Bulk SG(SSD) & \\
\hline 1 & Coarse aggregates & 2.56 & 2.60 & 2.63 & \multirow[t]{2}{*}{ 2.5-3.0 (ASTM C 618-2000) } \\
\hline 2 & Fine aggregates & 2.59 & 3.23 & 2.78 & \\
\hline 3 & Dangote OPC & \multicolumn{3}{|l|}{3.1} & 3.0-3.2 (ES,2005) \\
\hline 4 & MSWI fly ash & \multicolumn{3}{|l|}{2.28} & 1.9-2.8 (ASTM C 618-2000) \\
\hline
\end{tabular}

Table 4: The test result of silt content of fine aggregates.

\begin{tabular}{|l|l|l|l|}
\hline No & Physical properties of river sand & Percent & ES requirements \\
\hline 1 & Silt content & $5 \%$ & Not more than $6 \%$ \\
\hline
\end{tabular}

Table 5: The test result of sieve analysis of fine aggregates from $500 \mathrm{gm}$ of sample.

\begin{tabular}{|l|l|l|l|l|l|}
\hline Sieve size & $\begin{array}{l}\text { Weight of retained } \\
\text { (gm) }\end{array}$ & $\begin{array}{l}\text { Percentage of retained } \\
\text { (\%) }\end{array}$ & $\begin{array}{l}\text { Cumulative coarser } \\
\text { (\%) }\end{array}$ & $\begin{array}{l}\text { Cumulative passing } \\
\text { (\%) }\end{array}$ & ES C.D3.201 \\
\hline $9.5 \mathrm{~mm}$ & 1.60 & 0.32 & 0.32 & 99.68 & 100 \\
\hline $4.75 \mathrm{~mm}$ & 2.90 & 0.58 & 0.90 & 99.1 & $95-100$ \\
\hline $2.36 \mathrm{~mm}$ & 8.80 & 1.76 & 2.66 & 97.34 & $80-100$ \\
\hline $1.18 \mathrm{~mm}$ & 34.9 & 6.98 & 9.64 & 90.36 & $50-85$ \\
\hline $600 \mu \mathrm{m}$ & 162.7 & 32.54 & 42.18 & 57.82 & $25-60$ \\
\hline $300 \mu \mathrm{m}$ & 219.9 & 43.98 & 86.16 & 13.84 & $10-30$ \\
\hline $150 \mu \mathrm{m}$ & 61.0 & 12.2 & 98.36 & 1.64 & $2-10$ \\
\hline Pan & 7.80 & 1.56 & 99.92 & 0.08 & \\
\hline FM = Sum of Cumulative coarser/100 $=240.22 / 100=2.4$ & & & \\
\hline
\end{tabular}


Citation: Simegn A, Abebe S, Worku A (2021) Characterization and Optimization of Incinerated Municipal Solid Waste Fly Ash as a Cement Substitute Material in Concrete at Reppie Waste to Energy Plant, Ethiopia, East Africa. Adv Environ Stud 5(1):382-393

Table 6: The test result of sieve analysis of coarse aggregate from $2 \mathrm{~kg}$ sample.

\begin{tabular}{|l|l|l|l|l|l|}
\hline Sieve size & Weight of retained (gm) & Percentage retained & Cumulative coarser (\%) & Cumulative passing (\%) & ES C.D3.201 \\
\hline $75 \mathrm{~mm}$ & 0.0 & 0.0 & 0.0 & 100.0 & - \\
\hline $63 \mathrm{~mm}$ & 0.0 & 0.0 & 0.0 & 100.0 & - \\
\hline $37.5 \mathrm{~mm}$ & 22.9 & 1.15 & 1.15 & 98.85 & $\mathbf{9 5 - 1 0 0}$ \\
\hline $19 \mathrm{~mm}$ & 1043.1 & 52.16 & 53.31 & 46.69 & $\mathbf{3 0 - 7 0}$ \\
\hline $13.2 \mathrm{~mm}$ & 563.6 & 28.18 & 81.49 & 18.51 & - \\
\hline $9.5 \mathrm{~mm}$ & 248.4 & 12.42 & 93.91 & $\mathbf{6 . 0 9}$ & $\mathbf{1 0 - 3 5}$ \\
\hline $4.75 \mathrm{~mm}$ & 120.3 & 6.02 & 99.93 & 0.07 & $\mathbf{0 - 1 0}$ \\
\hline Pan & 1.3 & 0.07 & 100.0 & 0.0 & \\
\hline FM = Sum of Cumulative Coarser/100 = 329.79=3.3 & & & \\
\hline
\end{tabular}

Table 7: The test result of the moisture content of materials.

\begin{tabular}{|l|l|l|l|l|}
\hline No & Concrete materials & Weight before oven-dry (gm) & Weight after oven-dry (gm) & Moisture content (\%) \\
\hline 1 & Coarse aggregate & 2000 & 1965 & 1.78 \\
\hline 2 & Fine aggregate & 500 & 467.7 & 6.9 \\
\hline
\end{tabular}

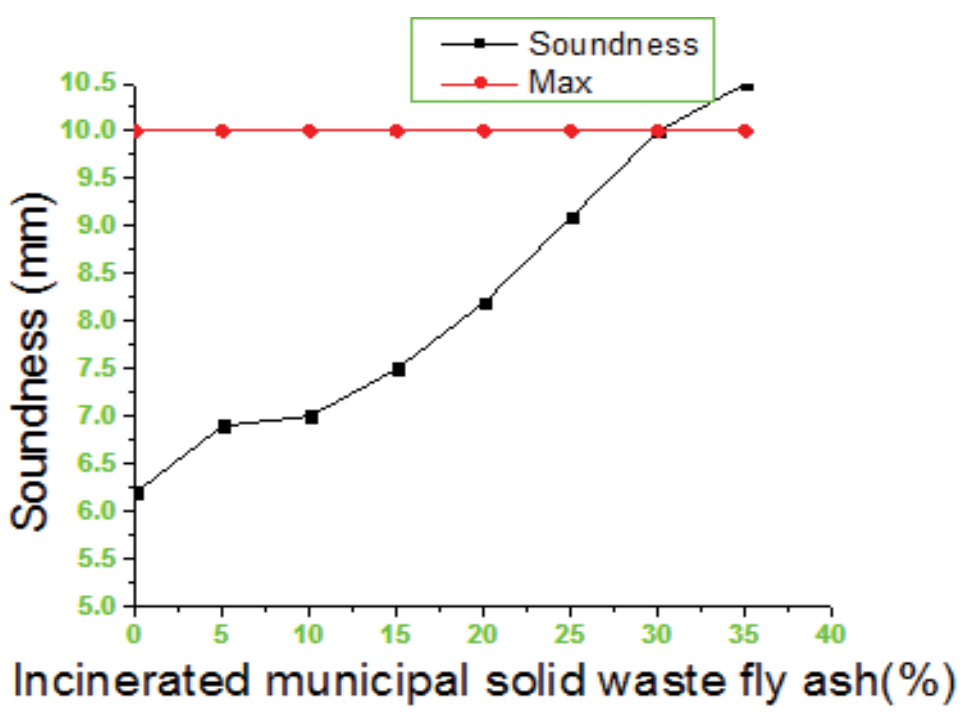

Figure 1: The soundness of blended cement.

ment $(10 \%, \max )$. The moisture content value for fine aggregate and coarse aggregate separately reported in Table 7.

The soundness of blended cement: The soundness of blended cement refers to the ability of cement not to shrink after hardening or the ability of hardened paste to maintain its volume after setting. From Figure 1, the soundness of the control paste or the paste without MSWI fly ash was found to be $6.2 \mathrm{~mm}$ and in range of ES [18]. Because Ethiopian Standard allows maximum soundness or expansion of cement paste up to $10 \mathrm{~mm}$. The test result as indicated in Figure 1.

Normal consistency of blended cement: The control paste or the paste without MSWI fly ash had a normal consistency of $26 \%$ and qualified the minimum specified requirements. Normal consistency of blended cement refers to the weight of water per weight of cement paste. Figure 2 indicated that all of the pastes containing incinerated municipal solid waste fly ash shown normal consistency higher than the control paste and this resulted due to incinerated municipal solid waste fly ash having a high rate of hydration property. Figure 2 shows that up to $30 \%$ of replacement qualifies the Ethiopian Standard because the usual range of water to cement ratio for normal consistency is between $26 \%$ and $33 \%$ [18].

\section{Setting Time of Blended Cement}

\section{Initial setting time of blended cement}

Initial setting time is the duration of cement past related to $25 \mathrm{~mm}$ of penetration in 30 seconds. Figure 3 indicated that an increasing percentage of MSWI fly ash speed up setting time up to $20 \%$ of replacement and qualified ES [18]. But significantly delayed setting time more than $20 \%$ of replacement and till qualifies minimum requirements of Ethiopian Standard. 


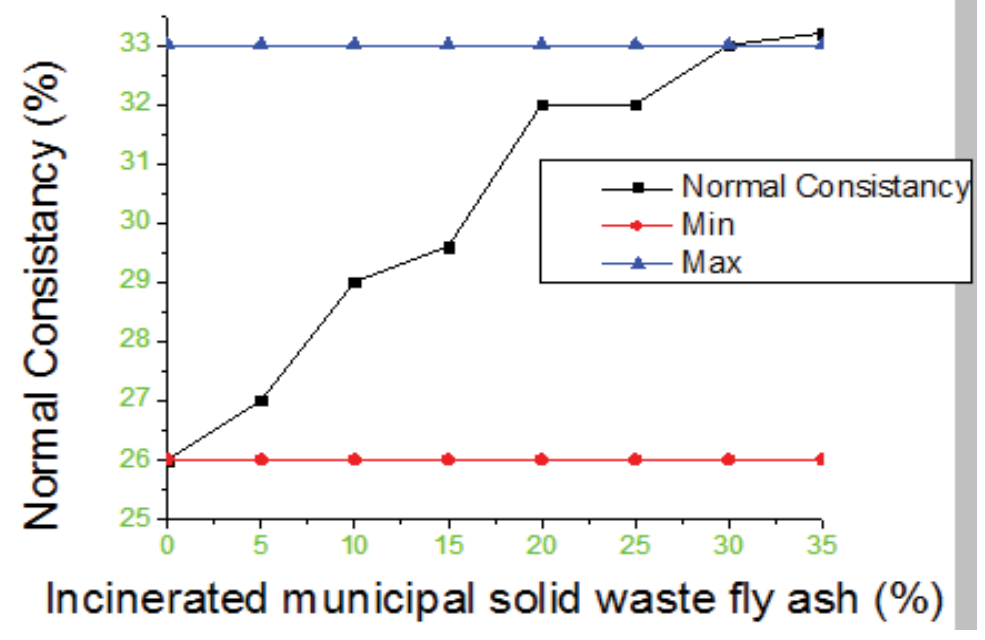

Figure 2: Normal consistency of blended cement.

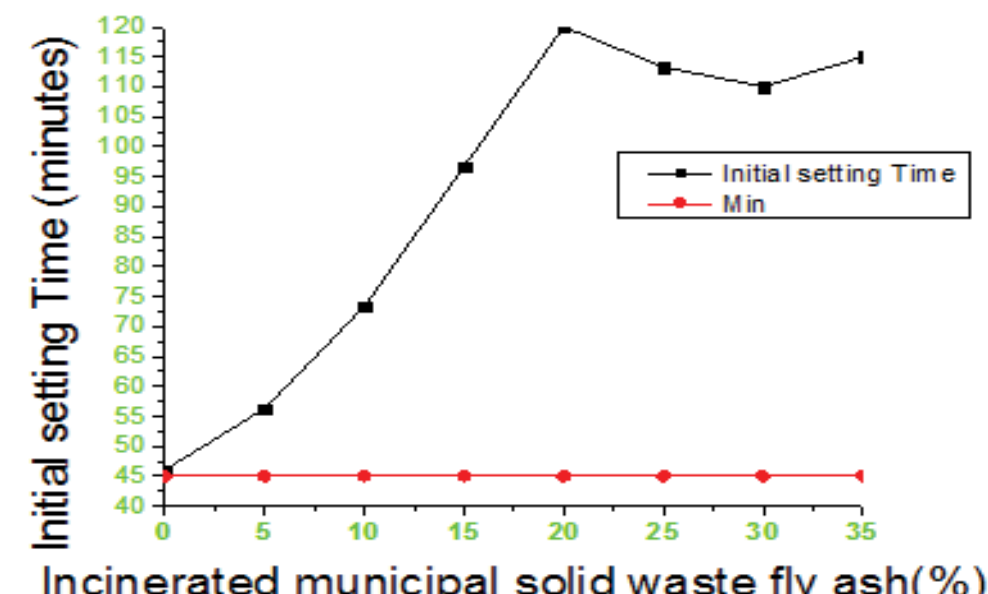

Figure 3: Initial setting time vs. blended cement.

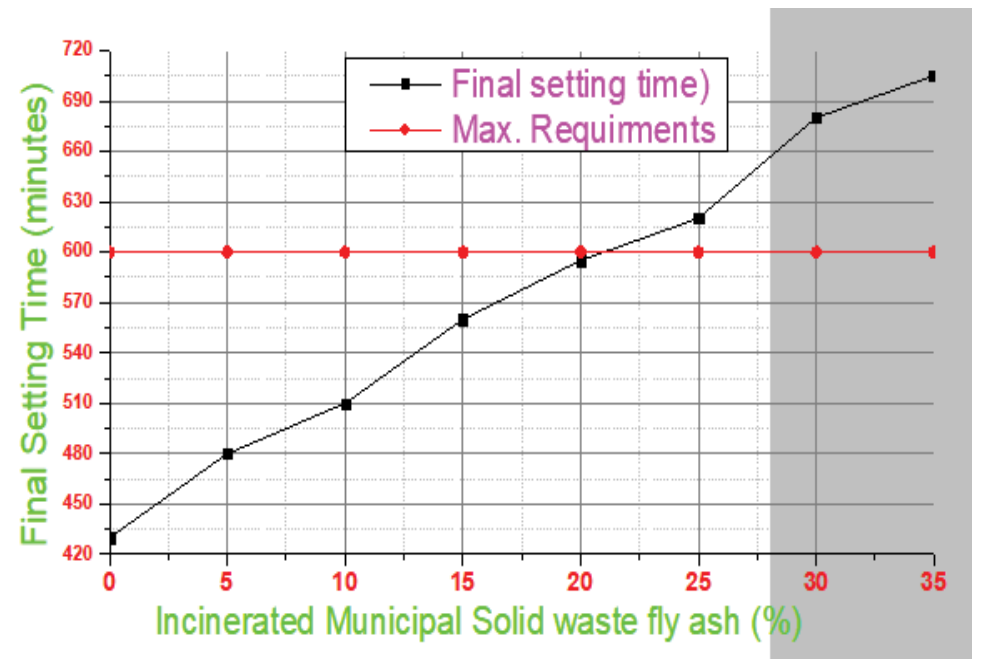

Figure 4: Final setting time vs. blended cement.

\section{Final setting time of blended cement}

Final setting time is the time at which cement completely loses its elasticity and becomes hard or it is the duration of cement past related to zero penetration depth. 
Citation: Simegn A, Abebe S, Worku A (2021) Characterization and Optimization of Incinerated Municipal Solid Waste Fly Ash as a Cement Substitute Material in Concrete at Reppie Waste to Energy Plant, Ethiopia, East Africa. Adv Environ Stud 5(1):382-393

The test results from the above Figure 4 indicated that the more MSWI fly ash content retarded setting time. However, this retardation for a final setting time was a qualified Ethiopian standard up to $20 \%$ of replacement while the final setting time significantly delayed after $20 \%$ of replacement. As per the Ethiopian standard limits the final setting time not to exceed 600 minutes [18]. Regarding this final setting, time can be adjusted by adding a cement accelerator to reduce the final setting time if you need to replace more than $20 \%$ of cement in concrete.

\section{Fineness modulus of blended cement}

Fineness modulus refers to the property of blended cement that indicates the particle size of cement and specific surface area.

As percentage replacement of MSWI fly ash increases, fineness modulus decrease and this resulted due to incinerated municipal solid waste fly ash is coarser than Portland cement Figure 5. The lower fineness modulus tends to increase the amount of bleeding and leads to the requirement of less water resulting in a higher possibility of dry shrinkage this because finer particles will be more completely hydrated than coarser particles.

Characteristics of concrete made of IMSW fly ash as a cement replacement material and its quality compression $\mathbf{M}-30$
A workability test result of fresh blended concrete sample: The experimental work shows that the workability of fresh concrete slightly decreases as the percentage replacement of incinerated municipal solid waste fly ash increases (Table 8). The decrease in the workability of the concrete is supposed to be due to the relatively high rate of hydration and this makes increasing water demand of fly ash as compared to ordinary Portland cement.

In general, some reduction in the slump by pozzolan was due to the fact that the cement was partially substituted by artificial pozzolan by weight and therefore the number of solids in the paste was higher than that of the control mixture due to the lower specific gravity of artificial pozzolan (2.28) compared to that of Portland cement (3.1) as a result of this more water is needed to lubricate particles [26].

\section{Compressive strength test result of hardened blended} concrete sample

The concrete cubes were cured in curing basin for 7 and 28 days and tested in compression thereafter according to ES [1].

The above Table 9 indicated that the average compressive strength of blended concrete decreases with increasing the percentage replacement of incinerated municipal solid waste fly ash content at both the curing period. The probable reason for this is due to the high replacement of MSWI fly

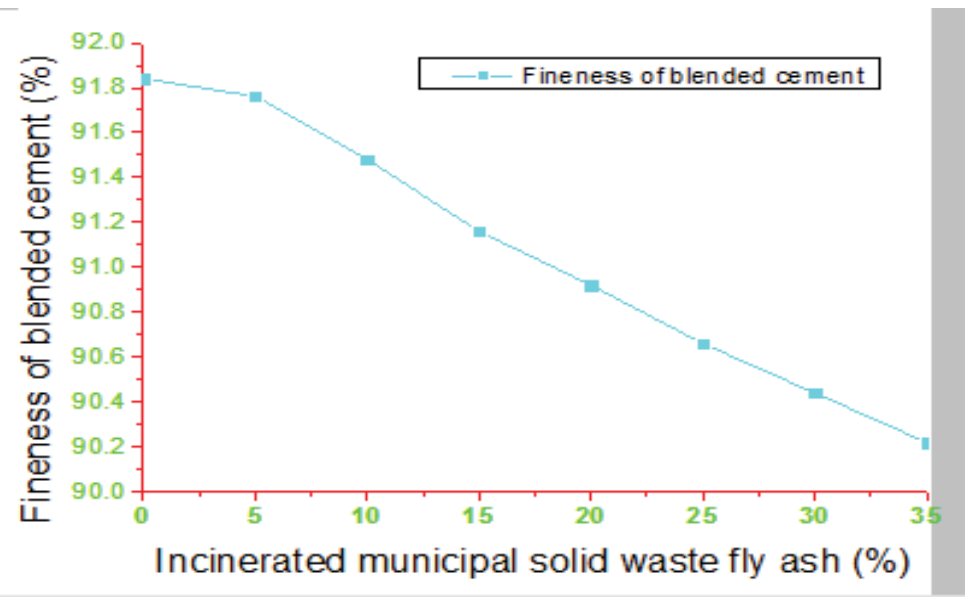

Figure 5: The fineness of blended cement.

Table 8: Test result of workability of fresh blended concrete sample.

\begin{tabular}{|l|l|l|l|l|}
\hline Mixed code & Replacement of IMSW solid waste fly ash & OPC & W/C (\%) & Observed slump (mm) \\
\hline RF@0 & $0 \%$ & $100 \%$ & 26 & 35 \\
\hline RF@5 & $5 \%$ & $95 \%$ & 27 & 30 \\
\hline RF@10 & $10 \%$ & $90 \%$ & 29 & 25 \\
\hline RF@15 & $15 \%$ & $85 \%$ & 29.6 & 23 \\
\hline RF@20 & $20 \%$ & $80 \%$ & 31.5 & 21 \\
\hline RF@25 & $25 \%$ & $75 \%$ & 32 & 18 \\
\hline RF@30 & $30 \%$ & $70 \%$ & 33 & 15 \\
\hline RF@35 & $35 \%$ & $65 \%$ & 33.2 & 14 \\
\hline
\end{tabular}


Citation: Simegn A, Abebe S, Worku A (2021) Characterization and Optimization of Incinerated Municipal Solid Waste Fly Ash as a Cement Substitute Material in Concrete at Reppie Waste to Energy Plant, Ethiopia, East Africa. Adv Environ Stud 5(1):382-393

Table 9: Average compressive strength of three cubic samples.

\begin{tabular}{|c|c|c|c|c|c|c|}
\hline \multirow[t]{2}{*}{ IMSW fly ash } & \multirow[t]{2}{*}{ OPC } & \multicolumn{2}{|c|}{ The average failure load of concrete in $\mathrm{kN}$} & \multicolumn{2}{|c|}{ Average compressive strength of concrete in $\mathrm{MPa}$} & \multirow[t]{2}{*}{ Remark } \\
\hline & & Day 7 & Day 28 & Day 7 & Day 28 & \\
\hline $0 \%$ & $100 \%$ & 510.97 & 765.04 & 22.69 & 33.94 & Reference \\
\hline $5 \%$ & $95 \%$ & 488.31 & 733.79 & 21.72 & 32.61 & \\
\hline $10 \%$ & $90 \%$ & 468.79 & 702.57 & 21.29 & 31.23 & \\
\hline $15 \%$ & $85 \%$ & 438.45 & 657.23 & 19.33 & 29.21 & \\
\hline $20 \%$ & $80 \%$ & 417.85 & 626.49 & 18.72 & 27.84 & \\
\hline $25 \%$ & $75 \%$ & 412.69 & 618.8 & 18.71 & 27.51 & \\
\hline $30 \%$ & $70 \%$ & 356.96 & 534.95 & 15.78 & 23.78 & \\
\hline $35 \%$ & $65 \%$ & 324.58 & 484.93 & 14.83 & 21.99 & \\
\hline
\end{tabular}

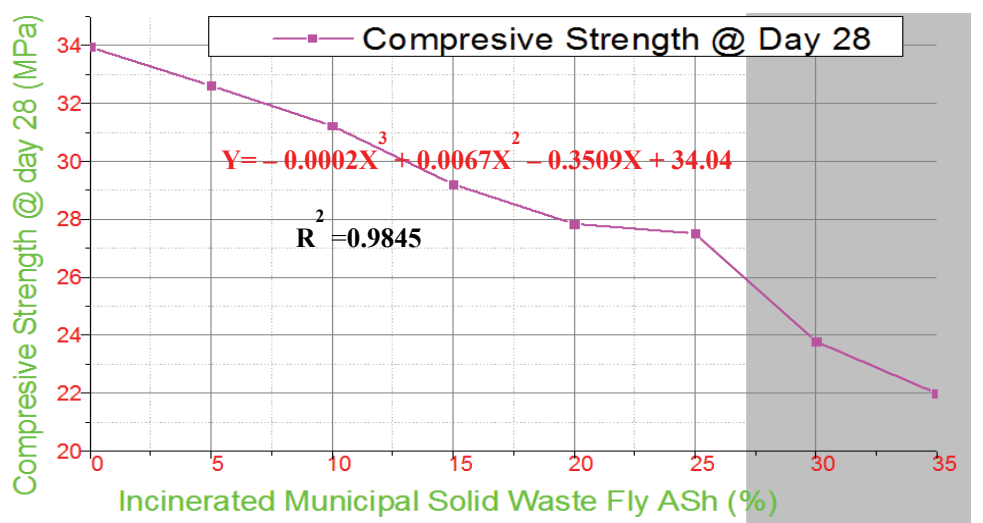

Figure 6: Compressive strength of blended concrete with a polynomial equation.

ash which has low calcium content by cement, thus reducing cement content of the mixture which in turn causes a reduction in the hydration reaction. In addition to this high content of MSWI fly ash resulted in a higher water requirement, making the water unavailable for the hydration of cement for further reaction. As a curing period increases, the compressive strength also increases at a constant mix proportion. The reason behind this, the pozzolanic effects of compressive strength enhancement is typically more pronounced in late age curing days than at an early age.

Pozzolanic cement strength is directly affected by the mineralogical characteristics of pozzolanic material such as particle size and surface area [26]. Continue to react with the calcium hydroxide formed by cement hydration as time goes by artificial pozzolan and increase the compressive strength by producing additional Calcium Silicate Hydrate and the pozzolanic reaction proceeds until there is no free calcium hydroxide available in mass. From Table 9 shows the results of sample tests taken on the $28^{\text {th }}$ day of curing period at $15 \%$, $20 \%$, and $25 \%$ replacement had a compressive strength of $29.21,27.84$ and $27.51 \mathrm{~N} / \mathrm{mm}^{2}$ respectively which is slightly less than the targeted value of compressive strength but all this percentage of replacement qualified $\mathrm{M}-25$ grade of concrete unless the mix design not changed. Whereas $5 \%$ and $10 \%$ of replacement completely over satisfied the targeted compressive strength. The strength expected to increase more than this value with further pozzolanic reactions in the subsequent curing periods.
To come up with appropriate percentage replacement of incinerated municipal solid waste fly ash at $30 \mathrm{MPa}$ of compressive strength formulating general equations recommended. By feeding all coordinate points listed in Table 9 such that $\{(0,33.94),(5,32.61),(10,31.23),(15,29.21),(20,27.84)$, $(25,27.51),(30,23.78),(35,21.99)\}$ using the application of ORGINPRO software. Compressive strength tests were carried out to determine the responses needed to formulate and validate the optimization function.

The equation of polynomial function indicated the graph in Figure 6 was generated by the reference software: " $Y=-$ $0.0002 X^{3}+0.0067 X^{2}-0.3509 X+34.04$ "and $R^{2}=0.9845$. Then using this equation it is very simple to compute exactly the percentage replacement of incinerated municipal solid waste fly ash at targeted compressive strength (30 $\mathrm{MPa}$ ) and then compute the value of percentage replacement or the values of " $X$ " exactly at $30 \mathrm{MPa}$ using the above polynomial equation: $-Y=-0.0002 X^{3}+0.0067 X^{2}-0.3509 X+34.04$ and make the value of $Y$ equal to $30 \mathrm{MPa}$. Then $0.0002 X^{3}-0.0067 X^{2}+$ $0.3509 X-34.043=-30$.

$0.0002 X^{3}-0.0067 X^{2}+0.3509 X+4.043=0$, will be the general equation at $30 \mathrm{MPa}$ and the specific percentage of replacement can be obtained by using the application of rational root test. Therefore the value of $X=13.6 \%$ at $Y=30 \mathrm{MPa}$.

Check the compressive strength at this value, $Y=$ $0.0002 *(13.6)^{3}+0.0067 *(13.6)^{2}-0.3509 *(13.6)+34.043=$ $30.0069 \mathrm{MPa}$, ok. 
Citation: Simegn A, Abebe S, Worku A (2021) Characterization and Optimization of Incinerated Municipal Solid Waste Fly Ash as a Cement Substitute Material in Concrete at Reppie Waste to Energy Plant, Ethiopia, East Africa. Adv Environ Stud 5(1):382-393

Table 10: Average of three tensile strength of a cylindrical sample.

\begin{tabular}{|l|l|l|l|l|l|}
\hline Mixed code & $\begin{array}{l}\text { IMSW fly } \\
\text { ash }\end{array}$ & OPC & $\begin{array}{l}\text { Average failure loads in } \\
\text { kN at 28 }\end{array}$ & $\begin{array}{l}\text { Average tensile strength in MPa at 28 } \\
\text { curing days }\end{array}$ & $\begin{array}{l}\text { EBCS-2, 1995 } \\
\text { requirements }\end{array}$ \\
\hline RF@0 & $0 \%$ & $100 \%$ & 263.01 & 3.723 & $3.4-5.1$ \\
\hline RF@5 & $5 \%$ & $95 \%$ & 254.14 & 3.597 & $3.3-4.9$ \\
\hline RF@10 & $10 \%$ & $90 \%$ & 237.47 & 3.361 & $3.1-4.7$ \\
\hline RF@15 & $15 \%$ & $85 \%$ & 205.39 & 2.907 & $2.9-4.4$ \\
\hline RF@20 & $20 \%$ & $80 \%$ & 180.37 & 2.553 & $2.8-4.2$ \\
\hline RF@25 & $25 \%$ & $75 \%$ & 175.77 & 2.488 & $2.7-4.1$ \\
\hline RF@30 & $30 \%$ & $70 \%$ & 165.673 & 2.345 & $2.4-3.6$ \\
\hline RF@35 & $35 \%$ & $65 \%$ & 106.75 & 1.511 & $2.2-3.3$ \\
\hline
\end{tabular}

Note: RF@0 means Reppie Fly ash at zero percent, OPC means Ordinary Portland Cement.

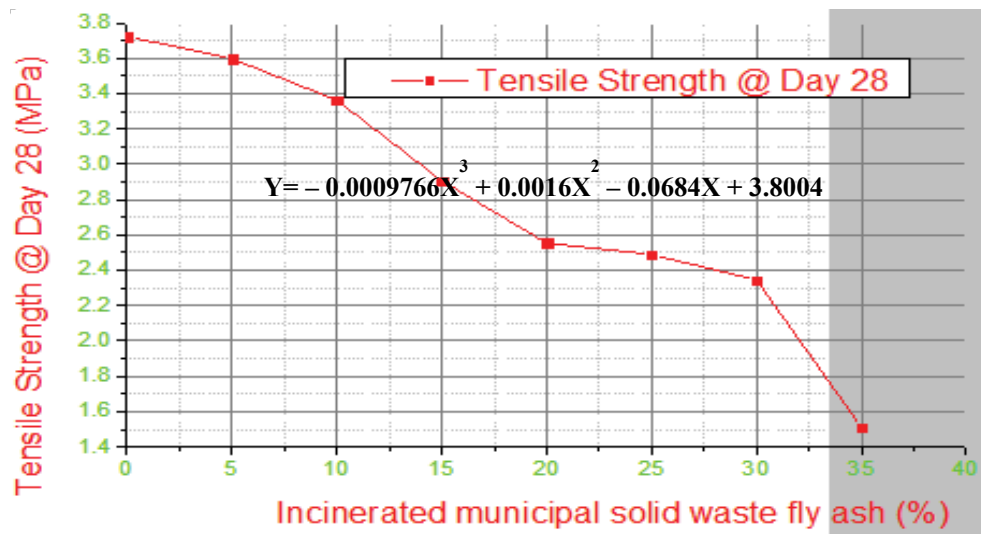

Figure 7: Tensile strength of blended concrete with polynomial equation.

In general, the strength continues to rise gradually as long as the water is available for continuous hydration, but concrete is typically allowed to dry out after a few days, which allows the growth of strength to stop [27].

Tensile strength test result of hardened blended concrete sample

Concrete develops cracks when tensile forces exceed its tensile strength. That is why we use steel reinforcement in reinforced concrete because of reinforcement bar strong in tension but not in compression and therefore, it is necessary to determine the tensile strength of concrete to regulate the load at which the concrete members may crack.Splitting tensile strength tests on the concrete cylinder is a method to determine the tensile strength of concrete. The tensile strength of concrete is one of the basic and important properties which greatly affect the extent and size of cracking in structures. The test result indicated in the table below directly summarized from the Appendix section as follows (Table 10).

Concrete is very weak in tension due to its brittle nature but strong in compression and hence, it is not expected to resist the direct tension. Tensile strength of concrete in general ranges from $10-15 \%$ of its compressive strength according to ES [1]. Therefore to check the percentage replacement of incinerated municipal solid waste fly ash at $13.6 \%$ the minimum requirements as per ES [1]. First polynomial equation was generated from the coordinate points listed $\{(0,3.723),(5$, $3.597),(10,3.361),(15,2.907),(20,2.553),(25,2.488),(30$, 2.345), $(35,1.511)\}$ :

$$
\text { “Y }=-0.0009766 X^{3}+0.0016 X^{2}-0.0684 X+3.8004 " .
$$

From the compressive strength of blended concrete, the optimum percentage replacement of incinerated municipal solid waste fly ash resulted at $13.6 \%$ and then check this value whether it qualifies the minimum tensile strength requirement as per ES or not [1]. Then the value of tensile strength at $13.6 \%$ replacement using the above polynomial equation becomes " $Y=-0.0009766 X^{3}+0.0016 X^{2}-0.0684 X+3.8004$ " and $\mathbf{R}^{\mathbf{2}}=\mathbf{0 . 9 5 9 3}$. Then substitute 13.6 at " $X$ " to get the value of " $Y$ " such that $Y=-0.0009766 *(13.6)^{3}+0.0016 *(13.6)^{2}-$ $0.0684 * 13.6+3.8004=\mathbf{3 . 0 6}$, ok because this qualifies ES [1] .

\section{Density test result of hardened concrete samples}

The density of the test sample at the age of the $28^{\text {th }}$ day for the different levels or proportions of incinerated municipal solid waste fly ash replacement was determined (Table 10). The experimental test results show that the density of the hardened concrete decreases with increasing the amounts of incinerated municipal solid waste fly ash percentage replacement and this is due to the lower unit weight or specific gravity of incinerated municipal solid waste fly ash comparable to ordinary Portland cement. The reduction in the density of concrete helps to decrease the self-weight of the concrete in 
Citation: Simegn A, Abebe S, Worku A (2021) Characterization and Optimization of Incinerated Municipal Solid Waste Fly Ash as a Cement Substitute Material in Concrete at Reppie Waste to Energy Plant, Ethiopia, East Africa. Adv Environ Stud 5(1):382-393

the determination of the design dead load of the concrete structural member to have reduced concrete cross-sectional dimension supporting the structural member and thus saves the amount of concrete volume relatively.

The polynomial equation makes simple to determine density at the optimum value of percentage replacement (13.6\%) and this makes simple to estimate a dead load of the structure during the structural design period. A denser concrete generally provides higher strength and fewer amount of voids and porosity. The general expression of the polynomial equation of density as a function of percentage replacement can be described as $\mathbf{Y}=\mathbf{0 . 0 0 0 7} \mathbf{X}^{4}$ $\mathbf{0 . 0 1 5 2} X^{3}+\mathbf{0 . 0 5 5 7} X^{2}-\mathbf{3 . 2 5 2 1 X} \mathbf{+ 2 4 0 2 . 2}$ (Figure 7), where $X$ represents the percentage of incinerated municipal solid waste fly ash and Y-represents dry density of blended concrete (Figure 8).

Water absorption test result of hardened blended concrete sample

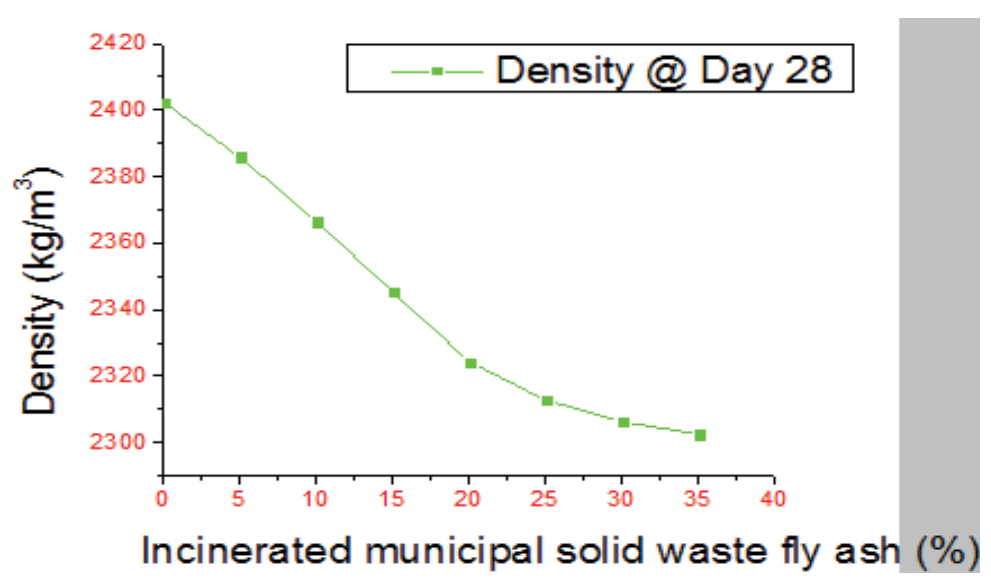

Figure 8: Density of hardened concrete as a function of scoria replacement.

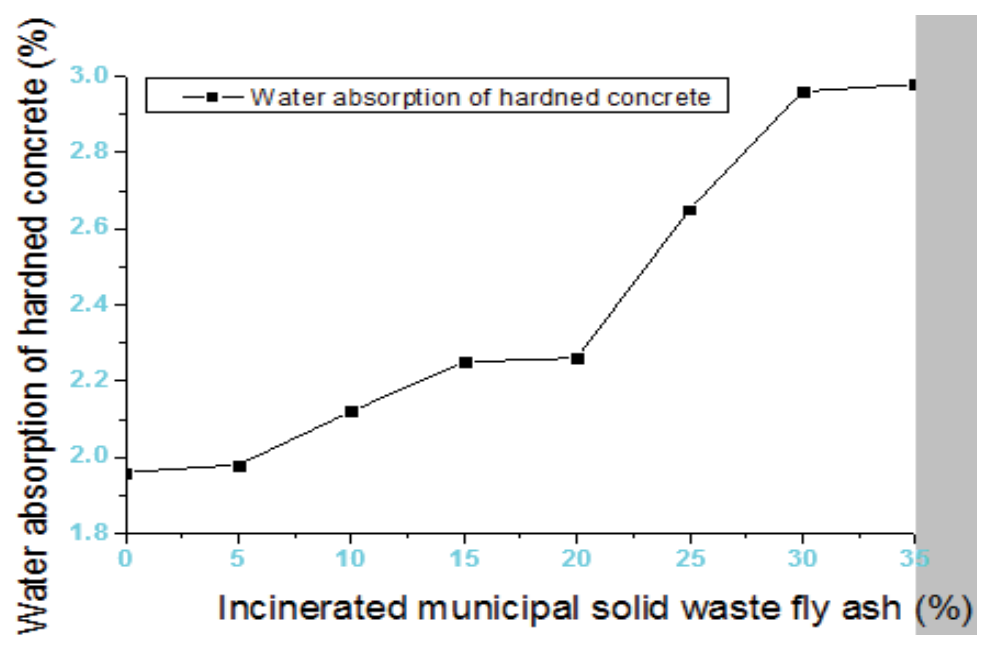

Figure 9: Water absorption of hardened concrete.

Table 11: Test result of water absorption of hardened blended concrete sample.

\begin{tabular}{|l|l|l|l|}
\hline Mixed code & IMSW fly ash & OPC & Average water absorption capacity at $\mathbf{2 8}^{\text {th }}$ curing days \\
\hline RF@0 & $0 \%$ & $100 \%$ & $1.96 \%$ \\
\hline RF@5 & $5 \%$ & $95 \%$ & $1.98 \%$ \\
\hline RF@10 & $10 \%$ & $90 \%$ & $2.12 \%$ \\
\hline RF@15 & $15 \%$ & $85 \%$ & $2.25 \%$ \\
\hline RF@20 & $20 \%$ & $80 \%$ & $2.26 \%$ \\
\hline RF@25 & $25 \%$ & $75 \%$ & $2.65 \%$ \\
\hline RF@30 & $30 \%$ & $70 \%$ & $2.96 \%$ \\
\hline RF@35 & $35 \%$ & $65 \%$ & $2.98 \%$ \\
\hline
\end{tabular}


Citation: Simegn A, Abebe S, Worku A (2021) Characterization and Optimization of Incinerated Municipal Solid Waste Fly Ash as a Cement Substitute Material in Concrete at Reppie Waste to Energy Plant, Ethiopia, East Africa. Adv Environ Stud 5(1):382-393

Water absorption of a concrete surface depends on many factors such as the presence of chemical admixtures and supplementary cementitious materials, the composition and physical characteristics of the cementitious component, the type, and duration of curing, the degree of hydration or age, the presence of surface treatments such as sealers or form oil and also strongly affected by the moisture condition of the concrete at the time of testing (Table 11).

As the incinerated municipal solid waste fly ash percentage replacement increases from $0 \%$ to $35 \%$, the average water absorption raising from $1.96 \%$ to $2.98 \%$. This means that the percentage of incinerated municipal solid waste fly ash content in the mix increases the concrete of low density has more voids and hence higher porosity. The other reason may be an increasing percentage of fly ash replacement results reduce the rate of hydration, less dense and this makes permeable to water molecules. Smaller the void in concrete, it becomes less permeable to water and soluble elements (Figure 9).

\section{Conclusion}

This study investigates the use of IMSW fly ash for cement replacement in the production of $\mathrm{M}-30$ grade of concrete. Incinerated municipal solid waste fly ash as investigated in this research work is promising to be used as a cement replacing material with environmental benefits. This incinerated municipal solid waste fly ash collected from Reppie Waste to Energy Plant can be assigned as class $C$ artificial Pozzolana, as per ASTM C 618 classification. The compressive strength and tensile strength of concrete made of incinerated municipal solid waste fly ash have shown a slight reduction as the percentage replacement increase at $28^{\text {th }}$ curing days from the control concrete. Hence, it can be concluded that ordinary Portland cement partially replaced with incinerated municipal solid waste fly ash up to $13.6 \%$ for M-30 grade of concrete which might be beneficial both environmentally and economically. Therefore concerned bodies should be made aware of this potential cement replacing material and promote its standardized production and usage for cement industries.

\section{References}

1. Ebcs-2 (1995) Structural use of concrete.

2. Gov HK (2015) Government of the Hong Kong special adminstrative region-waste $\&$ recycling municipal solid waste.

3. Tan Wen-Fa, Lv Jun-Wen, Deng Qin-Wen, et al. (2016) Application of a combination of municipal solid waste incineration fly ash and lightweight aggregate in concrete. Journal of Adhesion Science and Technology 30: 866-877.

4. Preda (2007) Managment of municipal solid waste in Europe report to environment. Agriculture and Local and Regional Affairs.

5. Lei $W$, Jin Y, Nieb Y, et al. (2010) Recycling of municipal solid waste incineration fly ash for ordinary Portland cement production: A real-scale test. Resources, Conservation and Recycling 54: 1428-1435.

6. Zacco A, Borgese L, Gianoncelli A, et al. (2014) Review of fly ash inertisation treatments and recycling. Environmental Chemistry Letters 12: 156-175.

7. Singh M, Deepak S (2017) Study on MSW incinerator ash in concrete with partial replacement of cement in RC beam. Environmental Science.
8. Sarmiento LM, Clavier KA, Paris JM, et al. (2019) critical examination of recycled municipal solid waste incineration ash as a mineral source for portland cement manufacture-A case study. Resources, Conservation and Recycling 148: 1-10.

9. Diamond S (1986) Particle morphologies in fly ash. Cement and Concrete Research 16: 569-579.

10. Bai Y, Ibrahim R, Basheer PAM (2004) Properties of lightweight concrete manufactured with fly ash, furnace bottom ash and lytag. Proceedings of the International Workshop on Sustainable Development And Concrete Technology, Beijing, China, 77-88.

11. Rendek E, Ducom G, Germain P (2006) Carbon dioxide sequestration in municipal solid waste incinerator (MSWI) bottom ash. J Hazard Mater 73-79.

12. Quina MJ, Bontempi E, Bogush A (2018) Technologies for the management of MSW incineration ashes from gas cleaning: New perspectives on recovery of secondary raw materials and circular economy. Science of The Total Environment 635: 526-542.

13. UNIDO (1994) The energy conservation center (ECC), output of a seminar on energy conservation in cement industry.

14. Ministry of Industry (2015) Impact of cement production to the environment.

15. Yang L (2012) Sustainability and innovative construction: Green building with concrete. Journal of Civil \& Environmental Engineering.

16. Li Y, Hao L, Chen X (2016) Analysis of MSWI bottom ash reused as alternative material for cement production. Procedia Environmental Sciences 31: 549-553.

17. Olusola (2010) MSWI ash improve concrete property.

18. Dinku (2002) Construction materials- laboratory manual by abebe dinku. Addis Ababa University.

19. Patterson SJ, Acharya SN, Bertschi AB, et al. (2004) Application of wood ash to acidic boralf soils and its effect on oilseed quality of canola. Agronomy Journal 96: 1344-1348.

20. ASTM C642 (2013) Standard test method for density, absorption and voids in hardened concrete.

21. Meeravali K, Balaji KVGD, Santhosh KT (2014) Partial replacement of cement in concrete with sugar cane bagasse ash-behavior in hcl solution. International Journal of Advance Research in Science and Engineering 3: 368-373.

22. Geremew M (2017) Bagasse ash as a partial substitute of cement on concrete rigid pavment. AAU Institutional Repository.

23. Zermeñoa RDV, Formosaab J, Chimenos JM, et al. (2013) Aggregate material formulated with MSWI bottom ash and APC fly ash for use as secondary building material. Waste Management 33: 621-627.

24. Helmuth R (1987) Fly ash in cement and concrete, Portland Cement Association. Journal of Cement and Concrete Research, 30: 201-204.

25. Thomas (1999) The calcium content of the fly ash is perhaps the best indicator of how the fly ash will behave in concrete.

26. Belle N, Soutos M, Gruyaert E, et al. (2018) Properties of fresh and hardened concrete containing supplementary cementitious materials: State-of-the-art report of the RILEM Technical Committee 238SCM, Working Group 4. RILEM State-of-the-Art Report.

27. Kosmatka SH, Kerkhoff B, Panarese WC (1988) Design and control of concrete mixtures. (14 $4^{\text {th }}$ edn), Illinois: Portland Cement Association. 